\title{
Landscape Perception and Public Participation for the Conservation and Valorization of Cultural Landscapes: The Case of the Cinque Terre and Porto Venere UNESCO Site
}

\author{
Antonio Santoro (D), Martina Venturi * and Mauro Agnoletti (D) \\ Department of Agriculture, Food, Environment and Forestry (DAGRI), University of Florence, 50145 Florence, Italy; \\ antonio.santoro@unifi.it (A.S.); mauro.agnoletti@unifi.it (M.A.) \\ * Correspondence: martina.venturi@unifi.it
}

check for updates

Citation: Santoro, A.; Venturi, M.; Agnoletti, M. Landscape Perception and Public Participation for the Conservation and Valorization of Cultural Landscapes: The Case of the Cinque Terre and Porto Venere UNESCO Site. Land 2021, 10, 93. https://doi.org/10.3390/land10020093

Academic Editor: Shiliang Liu Received: 23 December 2020

Accepted: 19 January 2021

Published: 21 January 2021

Publisher's Note: MDPI stays neutral with regard to jurisdictional claims in published maps and institutional affiliations.

Copyright: (c) 2021 by the authors. Licensee MDPI, Basel, Switzerland. This article is an open access article distributed under the terms and conditions of the Creative Commons Attribution (CC BY) license (https:// creativecommons.org/licenses/by/ $4.0 /)$.

\begin{abstract}
Europe retains a great variety of cultural landscapes that constitute a significant part of the European cultural heritage. In the last decades, these high-quality landscapes are facing several challenges due to socio-economic transformations that often compromise their integrity. This situation is even worse for terraced landscapes, as in the case of the Porto Venere and Cinque Terre UNESCO World Heritage List site. The Management Plan developed for this area needs to deal with different issues: abandonment of terraced cultivations and growth of secondary forests, hydrogeological risk and high touristic pressure. Public participation is increasingly important in the process of decision-making, for incorporating the ideas and the needs of the local communities, helping to find effective solutions for the valorization of historic landscapes and for improving the quality of life. This research has investigated the perception of the local community regarding the current landscape dynamics and other critical issues studying the opinions of two social groups: farmers and residents. The purpose was to identify the best management strategies for the Management Plan and to actively involve the population in the decisions. The involvement of the local community turned out to be a very effective tool for the development of the Management Plan, suggesting a focus on the conservation of dry-stone terraces and the reduction of reforestation processes, as the strongest perceived threat is the abandonment of cultivated terraces and the resulting risk of landslides. The methodology applied in this study can be reproduced in other cultural landscapes characterized by high quality, complexity and fragility, while an active involvement of the population turned out to be important also for increasing the feeling that institutions take care of its issues.
\end{abstract}

Keywords: landscape dynamics; forests; public perception; historical landscapes; agricultural heritage; UNESCO WHL; terraced landscape

\section{Introduction}

Europe, and in particular Mediterranean countries, retains a great variety of historical rural landscapes, due to the millenary human presence that has shaped the territory with agro-pastoral activities [1,2]. Nowadays, historical rural landscapes represent a significant part of the European cultural heritage [3]. In Europe, the traditional landscapes remained almost unchanged until the early twentieth century, when the great socio-economic changes that affected the entire continent led to major consequences for the rural world and its landscape [4-8].

Many cultural landscapes still have high qualities (in terms of environmental services, tourism attractiveness, high-quality food production, biodiversity, cultural and historical value), but in recent years, it is increasingly urgent to find solutions for their maintenance, in the perspective of sustainable development, both from an environmental and an economic point of view [9]. This situation is even more common for terraced landscapes, whose presence is widespread in Southern Europe. Despite their historical and aesthetic 
significance, or their role as a resource for agriculture and tourism, they are also a challenge for land conservation and management $[10,11]$.

Besides urban sprawl, two main factors are responsible for the landscape changes and the loss of a large part of the traditional agricultural systems in Europe: agricultural intensification in the most suitable areas for modern agricultural production on one hand, and the cultivations abandonment in mountain or marginal areas on the other $[12,13]$. These processes occurred with greater intensity in the Mediterranean basin $[14,15]$ than in the rest of the continent. Both of these dynamics, opposing each other, have led to the same result: a simplification of the structure of traditional landscapes and a loss of traditional activities and the biodiversity associated with them.

At the international level, two programs deal with the valorization of rural landscapes: the UNESCO World Heritage List (WHL) and the FAO (Food and Agriculture Organization) Globally Important Agricultural Heritage Systems (GIAHS). While in the case of UNESCO, rural landscape represents only a small number of the sites inscribed in the WHL, the FAO GIAHS program is only dedicated to rural areas. Despite these two important programs, degradation processes, such as abandonment, also occur in these areas.

One of the most important Italian cultural landscapes, Porto Venere and Cinque Terre, characterized by dry stone terraces of high aesthetic, historical and cultural value, has not been spared from the process of agricultural abandonment. In 1997, the UNESCO site "Porto Venere, Cinque Terre and Islands (Palmaria, Tino and Tinetto)" was established with the aim of safeguarding a fragile territory. As illustrated in the following sections in more detail, this landscape has to be considered fragile, as there are different driving forces, pressures, intrinsic characteristics and threats (socio-economical, environmental, hydrogeological) that jeopardize its maintenance. This area has been inscribed in the UNESCO WHL because it represents an outstanding example of the combined works of man and nature [16]. After the inscription in the WHL, in 1999, the Cinque Terre National Park was established. The two areas are not perfectly coincident, as the National Park is smaller, but for the majority of the surface, they overlap. One of the aims of the National Park, as made clear in the first point of Art. 3 of the Park Statute, is to "preserve, restore and valorize the historical agricultural landscape", and therefore the dry-stone terraces.

On 25 October 2011, a catastrophic event occurred. Heavy rains with peaks of $111 \mathrm{~mm} / \mathrm{h}$ and $350 \mathrm{~mm} / 6 \mathrm{~h}$ caused loss of lives, landslides and significant damage to the structures and to the economic activities [17]. As a result of the event and considering the damages occurred to the site, UNESCO asked Italian authorities to prepare a management plan for the site, in order to give indications to correctly manage the area.

In order to draft the Management Plan of the UNESCO site, it was necessary to identify management strategies that would deal with several critical aspects of a fragile and complex territory. As part of the working group for the drafting of the Management Plan, with the specific responsibility of the agro-forestry landscape, it was decided to actively involve the population. Due to the new challenges for the sustainable management of cultural landscapes, the perception of the landscape by the population is of strategic importance, since the European Landscape Convention (ELC), the document of the Council of Europe that promotes protection, management and planning of landscapes, defines landscape as "an area, as perceived by people, whose character is the result of the action and interaction of natural and/or human factors" [18]. Moreover, even the guidelines for the implementation of management plans for Italian UNESCO sites, compiled by the Ministry of Cultural Heritage and Activities and Tourism [19], demand to stimulate the active participation of residents in the protection of the site's cultural heritage.

Public participation in landscape planning and management has received increased attention across Europe since the European Landscape Convention came into force [20], for natural [21] and cultural landscapes, as well as for historic sites [22,23]. Public participation should play an essential part in the decision-making process, since it can incorporate the public's ideas, values and interests into decisions, resulting in more responsive and democratic governance [24]. Moreover, for those who study landscape transformations, 
it can contribute to verify the relationship between scientific research and the views and needs of the population [25-27]. The potential and suitability of involving local people in landscape management and planning is explicitly expressed in the Convention on Biodiversity [28], the European Landscape Convention [18] and the Aarhus convention [29]. Moreover, it is known that it is not possible to sustain the "intimate interaction between communities and land" by government intervention alone [30], without involving the local communities [31]. In fact, the people who inhabit a place have important perceptions and attitudes about planning issues and integrating social and perceptual information could improve the understanding of the impact of landscapes changes on the people who inhabit them [32]. Perception and aesthetic appreciation of a landscape depend on many factors, some of which are common to everyone and are stable in time and space. Other factors are determined by the social context in which a person lives. The perception of the landscape may be modified over time with changes to the territorial system, landscape and society that produced it. Both rural and urban landscapes have always been subjected to drastic transformations because "they are the expression of the dynamic interaction between natural and cultural forces in the environment" [3].

The goal of this research is to evaluate landscape perception and public participation for the drafting of a UNESCO site Management Plan, collecting data on the main issues and needs of the local community. This was done by analyzing the opinions of two social groups: farmers, who, through their work, conserve the cultural landscape, and residents and workers within the UNESCO site, who benefit daily from this territory. The purpose was to obtain information to support the strategies of the Management Plan, taking into account the real needs of an area with specific issues: crop abandonment, hydrogeological risk and management of tourism. In fact, this unique cultural landscape can be preserved only by actively involving those who still cultivate the land, with the support of the institutions and of the rest of the resident population, in order to try to apply a sustainable management model. Moreover, this methodology can be reproduced in other UNESCO sites' Management Plans. In fact, while public participation and the involvement of the local communities are recognized as fundamental for landscape and territorial planning, their use in addressing the UNESCO sites' Management Plans is not so widespread.

\section{Materials and Methods}

\subsection{The Study Area}

The UNESCO Site "Porto Venere, Cinque Terre and Islands" extends for about 4700 ha in the Region of Liguria, in northern Italy (Figure 1). It comprises a very steep coastline where the human communities have adapted themselves to this rough and inhospitable territory by building settlements and by cultivating land and creating a unique and remarkable cultural landscape. Since the 12th century, the work of farmers has transformed the slopes into an intensively terraced landscape in order to make it suitable for agricultural activities, mainly for cultivating vines and olive trees [33,34]. Terranova [35] reported, for the Cinque Terre region, densities of 3300-6000 m of dry-stone walls per hectare, with a total length of the walls equal to about $6700 \mathrm{~km}$. The area is characterized by Mediterranean climate, with warm winters and hot summers with frequent periods of drought. The average annual rainfall is equal to $1343 \mathrm{~mm}$, with maximum peaks in autumn and spring. The mountain range runs parallel to the coast and despite the limited altitudes, due to the short distance from the sea, it causes a pronounced steepness of the whole territory. The hydrographic network consists of small streams, which frequently cause hydrogeological problems, such as erosion and landslides. 


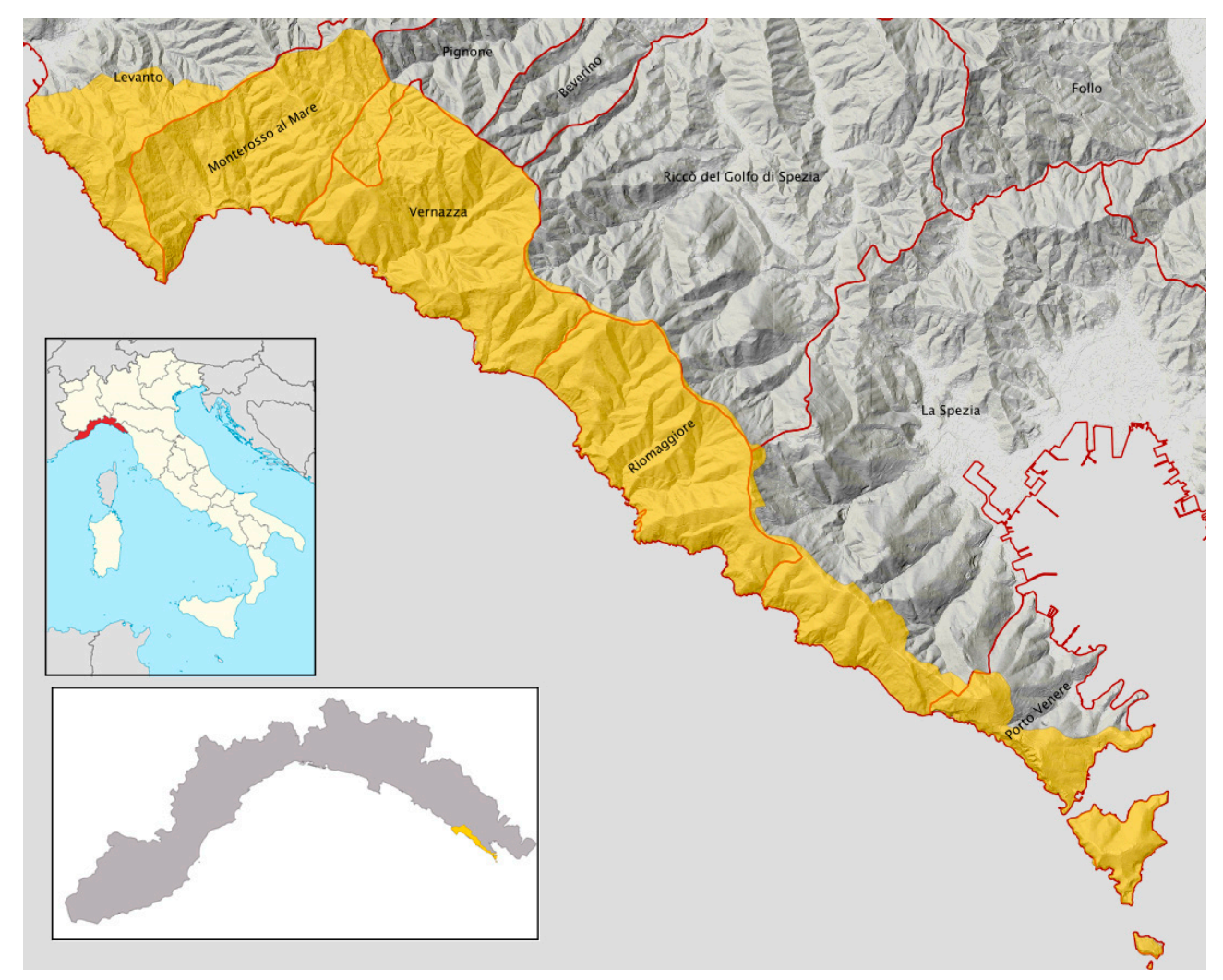

Figure 1. The UNESCO Site "Porto Venere, Cinque Terre and Islands" extends for about 4700 hectares along the steep coast of Liguria Region (small map on the lower left), in northern Italy.

The territory of Cinque Terre and Porto Venere has been inscribed into the UNESCO WHL according to criteria (ii), (iv) and (v), with the motivation that it embodies "a cultural site of outstanding value, representing the harmonious interaction between people and nature to produce a landscape of exceptional scenic quality that illustrates a traditional way of life that has existed for a thousand years and continues to play an important socioeconomic role in the life of the community" [36]. Thus, the reason for the inscription of this territory in the UNESCO WHL has to be found in the unique landscape, made of dry-stone terraces on steep slopes, built by men over the centuries [16]. Nowadays, terraces allow the cultivation of vines, olive trees, citrus trees and vegetables. Vineyards are the most widespread cultivation, carried out using the traditional pergola bassa technique, with the branches of the vines that grow on a pergola $80-130 \mathrm{~cm}$ high [37].

Since the end of World War 2 (WWII), this territory has undergone many socioeconomic as well as environmental and land use changes that are currently threatening the historical landscape of terraced cultivations. The causes, threats, pressures and driving forces are manifold but can be summarized in a few key points to provide a complete framework to the readers:

- Socio-economic situation: As in the majority of rural and marginal areas of Italy, Cinque Terre and Porto Venere also suffered from a significant depopulation. In the period 1931-2011, the depopulation in the municipalities touched by the UNESCO site (Porto Venere, Riomaggiore, Vernazza, Monterosso al Mare, Levanto) was equal to $-34.5 \%$.

- Crisis of agriculture: Statistics on agriculture for this territory highlight the crisis of this sector, at least from the beginning of the twentieth century. As it has happened in many European rural landscapes, the management regime these activities developed under is no longer economically feasible [9]. In the territory of the municipalities interested by the UNESCO site, there has been a decrease in the number of farms equal to $-76 \%$ in the period 1929-2010, and a decrease of the Utilized Agricultural Surface (SAU) 
equal to $-46 \%$ in the period 1971-2010. Since 1929, the two main cultivations (vines and olive trees) began to suffer a strong decrease, with a reduction in their surfaces respectively equal to $-85 \%$ and $-75 \%$ [38,39]. Among the main causes of the decline of the local agricultural sector are: the difficulties inherent in practicing agriculture on terraces, since among the agricultural areas, terraced slopes are often the first to be abandoned due to accessibility and economic limitations [11], the fragmentation of the properties, since $61.6 \%$ of the farms are smaller than 2 hectares, the high average age, with $36 \%$ of the farms managed by persons aged over 75 years and only $3.8 \%$ led by people 35 years or younger [38], and the low level of technology in the management of the farms.

- Spread of woodlands: The abandonment of agricultural activities caused the increase of woodlands and shrubland from 55\% to 77\% of the territory in the period 1973-2010. The increase in wooded areas and the resulting simplification of the landscape led to a decrease in biodiversity, as landscapes rich in biocultural diversity are often those resulting from small-scale farmers and traditional practices and with a complex landscape structure [40], that can provide a variety of environments and microhabitats. Forest increase is not only the result of the socioeconomic change but also of the environmental thinking and protection strategies, applied by managing authorities, favoring the re-naturalization of the territory $[41,42]$.

- Hydrogeological risk: The main consequence of the abandonment of the terraces and spread of newly established woodlands is the landslides and erosion increase. As a matter of fact, the role of managed terraces in slope stability is reported for multiple environments, as well as the effects of abandonment on marginal areas [43-49]. Abandonment of terraces is often followed by slope colonization by pioneer species, terrace degradation, hydrogeological hazards and diffuse slope instability phenomena [50-53]. In the Cinque Terre, as well, recent landslides are directly related to the abandonment of the terraces, due to the fact that the area is characterized by a high slope gradient. A study on the detachments of the landslides after the floods of October 2011 highlighted that $45 \%$ of detachments occurred in areas occupied by forests or shrublands, $47 \%$ occurred in recently abandoned terraces and only $6 \%$ on cultivated terraces [50].

- Tourism: Historical cultural landscapes are an important factor of attraction for rural areas, where rural tourism often represents an alternative and economic diversification that guarantees a higher income for the local population than the traditional agricultural activities [54-56]. Tourism, however, can also be a negative element. The territory of the UNESCO site, due to its widespread reputation, has become in recent years one of the main Italian tourist destinations. This has led to the presence of a large number of tourists in a small-sized and highly fragile territory, with consequent problems due to the lack of management of tourist flows, the maintenance and the crowding of the paths (too many people on small unpaved paths can cause soil compaction and consequent increase of erosion and runoff after the rain) and the fact that tourism-related activities are replacing agriculture as the main income. In fact, in the municipalities included in the UNESCO site, $33 \%$ of economic activities are accommodation and restaurant activities and 22\% are trade-related [57], confirming the central role of the tourism industry.

- Territorial Planning: Besides being a UNESCO Site, this territory is marked by the presence of the Cinque Terre National Park, the Regional Natural Park of Porto Venere, five Sites of Community Importance (SCI), different municipalities, a Province and a Region. There is, therefore, the need for a better coordination between the different levels of territorial planning, to face the various challenges in a coherent way.

All such pressures, driving forces and different characteristics, led to a high degree of complexity for this fragile territory, with the consequence that planners and managers have to deal with a wide range of issues (economic, social, environmental, etc.) for providing a sustainable future, as often happens for traditional cultural landscapes [9]. 
Although the overall situation may seem rather negative, there are recent initiatives with a positive impact. The spread of organic farming, the agricultural cooperatives, the use of rural development funds for the restoration of dry-stone walls and for monorails, can all contribute to increase once again the surface used for traditional crops. Moreover, in the last few years, a number of young people have decided to restore the terraces that belonged to their families and to cultivate them again. These efforts show a will of the population to face the issues and take care of the territory. Such initiatives are well worthy of attention and must be taken into account by the institutions.

\subsection{The Methodology and the Use of Questionnaires}

The methodology applied to investigate the landscape perception and to identify the main needs and threats has been based on questionnaires. The use of questionnaires in landscape perception studies has been attested since the 1980s, especially for research on static aspects and qualities of the landscape [58-62]. Questionnaires can be used directly in the field or at distance through computer-based surveys according to the sample to be surveyed and with different methodologies regarding data elaboration, correlation with spatial analysis, construction of the questionnaires and aim of the study [63-66]. More recently, the use of pictures, photomonatages or virtual images has spread to assess public preferences or the relation between landscape perception and ecological health and/or fitness [67-70].

In our survey, two types of questionnaires have been distributed, to be filled in anonymously: Questionnaire A for residents and workers (Appendix A), and Questionnaire $B$ for farmers (Appendix B). The questionnaires were structured so as to obtain information that can be easily statistically processed, that would provide answers about the perception of the local landscape and its features, the main problems of the area and the role of public bodies in land management. At the beginning of the questionnaire, a brief introduction was added containing the motivations of the inscription of the site in the UNESCO WHL, the reason for the survey and the list of participants in the workgroup for the drafting of the UNESCO Site Management Plan.

The questionnaires were structured into four different parts, as follows.

The first part has been set to collect personal information, including age, gender, education level, municipality of residence and occupation.

The second part dealt with the issues of landscape perception, with questions about the biggest changes perceived, the role of the woodland, the various landscape features and the role of agriculture. In the same part of the questionnaire, a photomontage has been inserted to investigate the perception in order to identify characteristics of the local landscape and the relationship between forest and agriculture. An actual picture of the terraced coast cultivated with the pergola bassa technique has been modified by increasing or reducing the presence of the forest in favor of vines, in order to simulate more cultivated or more abandoned/seminatural scenarios.

The third part focused on the role of the Parks, on the main threats as perceived by residents and farmers and on possible economic investments in order to minimize the critical issues and preserve the cultural landscape of terraces.

A fourth part has been added in the questionnaire tailored to farmers to investigate specific farming-related issues. The questions focused on the multi-functionality of the farm, on services for tourists offered by the farm, on the provenance of tourists, on farm characteristics (products, type of viticulture, marketing and certification of the products), on projects funded by the Rural Development Programs and on the issues and the possible solutions to improve the quality of life of the farmers.

Questionnaires to residents were distributed during different days, in different parts of the territory included in the UNESCO site, simply asking people if they wanted to participate in the survey. Questionnaires for farmers were distributed with the help of the local Cinque Terre Cooperative, and as a result, almost all the local farmers have answered the questions. 


\section{Results}

Below are the main results of the questionnaires, highlighting the significant differences between the perception and expectations of residents and producers. An interesting fact comes from the difficulty of obtaining information from residents in the first phase of the survey. In fact, at the beginning, many residents refused to answer the questionnaires, complaining about the lack of attention from local institutions towards their needs, but after having explained to them the purpose of the survey also through some meetings with the population organized in the framework of a bigger participative process for the Management Plan, they started sharing their opinions and experiences. The total number of respondents is equal to 212 residents and workers and 120 farmers. The results are divided into:

- Socio-cultural characteristics of the respondents

- Landscape perception

- The role of the institutions and expectations for the future

- Farms' characteristics, multifunctionality of agriculture and tourism (only for farmers)

\subsection{Socio-Cultural Characteristics of the Respondents}

Age and gender: The characteristics of the people who answered the questionnaire, regarding gender, age groups and distribution in the municipalities included in the UNESCO site, are representative of the local social situation. Regarding the farmers, $49 \%$ of them are over 60 years old, but a good percentage (26\%) are under 45 , highlighting an interesting generational turnover.

Level of education: 55\% of the residents and workers completed high school and $27 \%$ are university graduates. Overall, the sample has a medium-high level of education, therefore we expected a fairly high sensitivity toward the themes of landscape protection and a considerable awareness of the respondents about living in a high-value territory. The average level of education of farmers is lower (32\% completed high school and 6\% have a university degree). This is mainly due to the low level of education that characterized the rural territories of Italy until the middle of the twentieth century.

Professional occupation of residents and workers: Among the residents, three main categories can be identified: traders (17\%), employees of accommodation facilities or restaurants $(11 \%)$ and managers of accommodation facilities or restaurants $(12 \%)$. Altogether, these categories represent $40 \%$ of the respondents, excluding students $(6 \%)$ and retirees $(17 \%)$. It emerged that most of residents are employed in the tourism and trade industries. The level of unemployment in the sample was very low.

\subsection{Landscape Perception}

Identification of the most significant landscape change in recent years: For both groups, the most significant change perceived is the abandonment of the territory and of the cultivations. This answer was chosen by $53 \%$ of residents and workers, and by $93 \%$ of farmers. Residents also reported an increase in landslides (22\%) among the main problems, while the spread of the woodland was chosen as the main problem by $7 \%$ of the residents and $5 \%$ of the farmers.

Importance of the different landscape features: The perception of the role of the forest within the UNESCO site is one of the main elements of difference between residents and farmers: $63 \%$ of surveyed residents consider the woods a fundamental feature of this landscape, compared with $9 \%$ of farmers (Figure 2 ). 
Does the wood represent a fundamental feature of the landscape of the UNESCO Site? - Residents

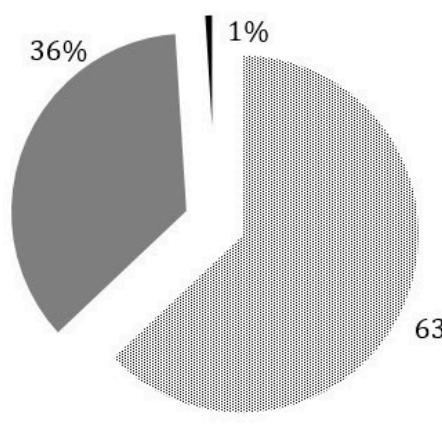

in Yes, a lot

- No, not much

- I don't know
Does the wood represent a

fundamental feature of the landscape of the UNESCO Site?-Farmers

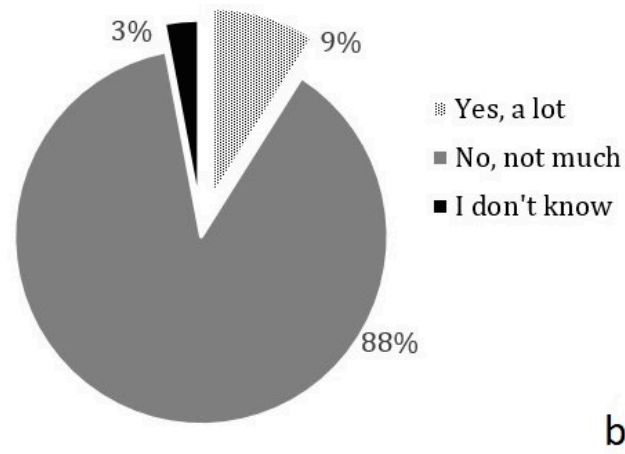

Figure 2. The perception of the woodlands resulting from abandonment of terraced cultivation is considerably different in (a) residents and (b) farmers.

To verify the importance of the main land uses, the respondents were asked to assign a score from 1 to 5 based on the importance of the different features (Figure 3). The value attributed by residents and workers to the different landscape features are on average high, the only low score is related to pastures, a land use that disappeared from the territory many years ago, and of which remains almost no trace in the memory of the population.

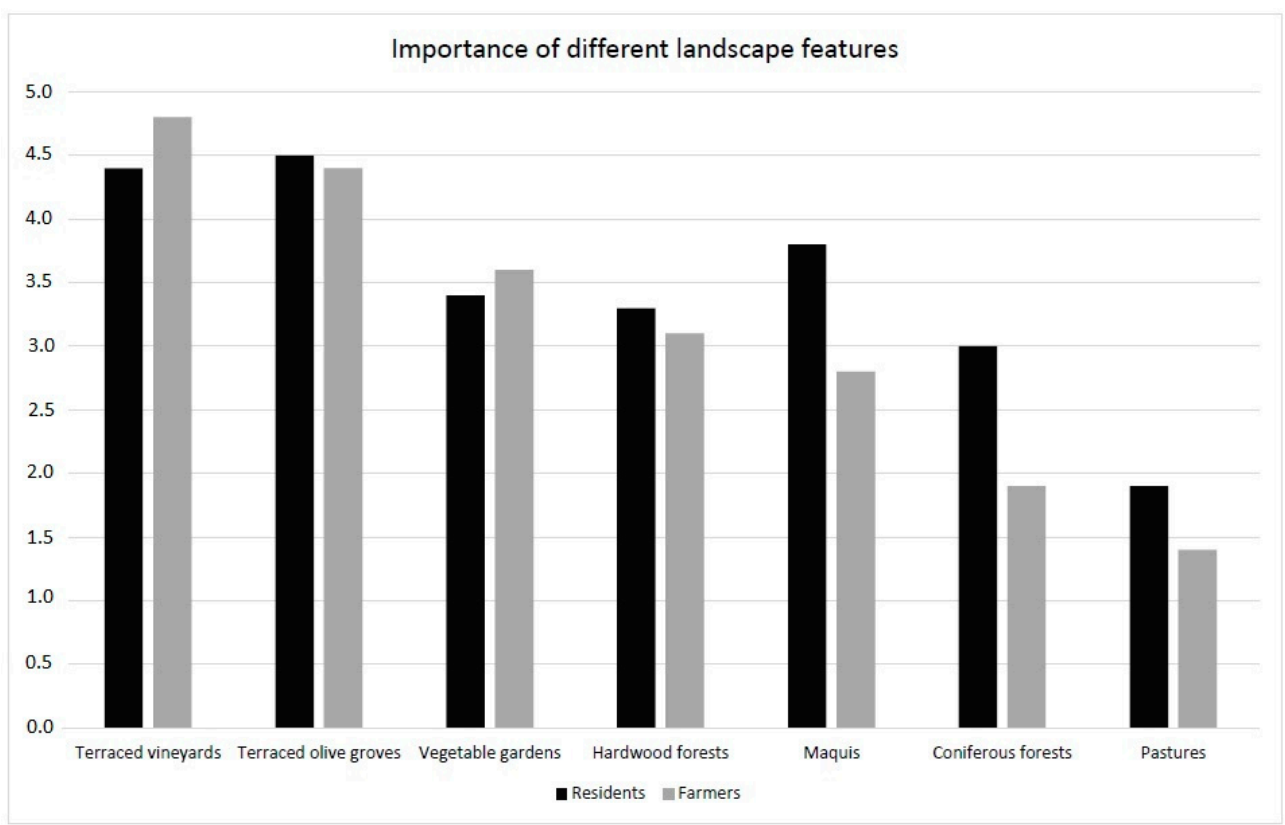

Figure 3. The importance of different land uses according to the opinion of farmers and residents. Traditional terraced land uses are the ones that are considered as the most important landscape features by both residents and farmers.

The value attributed to terraced vineyards and terraced olive groves are the highest for both groups, and the importance given by farmers to vineyards and vegetable gardens is higher compared to the perception of the residents. Further interesting data concerns the scores given to woodlands and shrublands. These values show that residents have a propensity to perceive the overall environment around them as important, not only the man-built landscape but also the seminatural and spontaneous one. 
Although the values assigned by farmers are lower and despite the fact that they do not perceive the woodland as a fundamental feature of the surrounding landscape, the deciduous forests received high scores on average.

The photomontages: To further reinforce the perception of the cultural landscape, the abandonment of crops and the increase of the forest, a photomontage of a terraced slope was prepared. The intermediate level (photo B) is a real photo of a slope with traditional terraced vineyards and with some woods. Then, two other scenarios have been realized increasing the woodlands (photo C) or the terraced vineyards (photo A) (Figure 4). We asked residents and farmers to choose what kind of landscape they prefer and that best represents the place: $94 \%$ of farmers opted for the same answer, with a clear preference towards a mainly terraced and cultivated landscape (photo A), while among the residents, the preference for the same landscape is lower ( $78 \%$, while $22 \%$ preferred photo $B$ ), but still predominant.
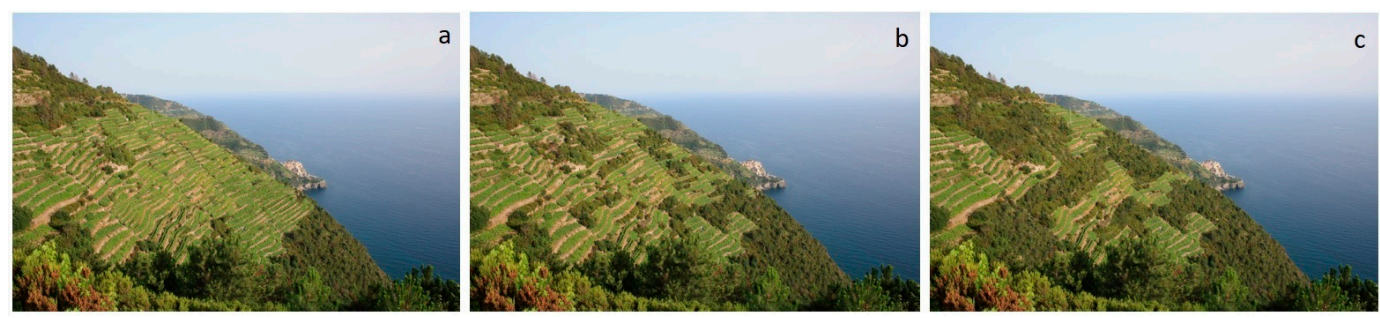

Figure 4. Photomontages have been used to investigate landscape perception and preferences: (a) a lower degree of abandonment of cultivations, (b) the real situation and (c) a higher abandonment of cultivations.

\subsection{The Role of the Institutions and the Expectations for the Future}

The role of the Parks: In order to understand the opinions about the role of the Parks in protecting the territory, the population were asked if they perceive a change since the National Park of Cinque Terre (1999) and the Regional Natural Park of Porto Venere (2001) were established. The awareness of residents of the presence of two parks is high, with only $1 \%$ of the sample not able to determine if they reside or work inside one of the two parks, and $65 \%$ of the respondents stated that they have perceived a change. Most of these changes, however, are seen as negative by residents. Many answered that the creation of the Parks merely resulted in increased tourism, and this is not always perceived positively. Tourism initially brought benefits to life and to local economy, but later caused a decline in the quality of life due to overcrowding and loss of basic social services (school, pharmacy, post office, etc.). The Parks are considered to excessively focus on tourism marketing, rather than investing in effectively restoring and maintaining dry-stone terraces. As far as the farmers are concerned, they have been asked to identify the main problems related to their specific activities. Excessive bureaucracy is the most frequently mentioned one $(85 \%)$, followed by workforce availability $(73 \%)$, damages caused by wildlife $(69 \%)$, lack of awareness by the tourists of the characteristics and of fragility of the territory $(68 \%)$ and the lack of adequate roads and paths (57\%). Of the farmers, $67 \%$ identified the National Park as the institution that should primarily take care of land management.

Threats and expectations for the future: One of the main threats for residents is related to landslides and erosion, and the investments towards the mitigation of hydrogeological risk are considered a priority, followed by investments in the protection of the cultural landscape and agricultural activities. Natural aspects appear to be secondary to landscape and agriculture, confirming that the UNESCO site is perceived as a place of conservation of a cultural landscape heritage rather than of naturalistic features. Tourism has also been chosen as a relevant sector of intervention, not with the purpose of increasing the number of tourists, but to improve its management and change its characteristics. According to farmers, there are two main priority sectors of investments: tourism, chosen by $27 \%$, and creation of a network of farmers, chosen by $24 \%$. Farmers ask for public support for 
investment in rural hospitality and policies to implement a more sustainable tourism, based on the discovery of local products, making the farm the main reference point for the tourists. Another $21 \%$ of farmers chose the theme of nature, particularly with regard to wildlife management, since it is perceived as a relevant problem due to the damages caused by wildlife and the costs of fencing off agricultural areas. The theme of the hydrogeological risk was chosen by $17 \%$, because they consider that the costs of management and maintenance of the dry-stone terraces cannot fall entirely on farmers, since the entire community takes advantage of it.

\subsection{Farms Characteristics, Multifunctionality of Agriculture and Tourism (Farmers' Questionnaires Only)}

Characteristics of the farms: Agriculture is the main activity for only $13 \%$ of farmers, suggesting that the agricultural economic system, as it is currently organized, is not viable enough to ensure a fair income for farmers. The surveyed farms have an average size of about 1.5 ha, with only four properties that exceed 5 hectares (Figure 5): 80\% of the farmers deliver their grapes to the wine cooperative, so only a minority of the respondents produce wine directly from the farm. Despite the small size of the properties, $82 \%$ of respondents stated that they own uncultivated plots, highlighting how abandonment also involves active farms, mainly because of the difficulty to access some fields, or for the high costs of putting terraces back into production that have been left uncultivated for years, on which trees and shrubs have grown. A lack of cooperation between farmers is also noticeable: about $90 \%$ of them work individually without collaboration with other farmers. Cooperation, especially for sharing equipment or for common agricultural operations, although viewed positively by the farmers themselves, is uncommon.

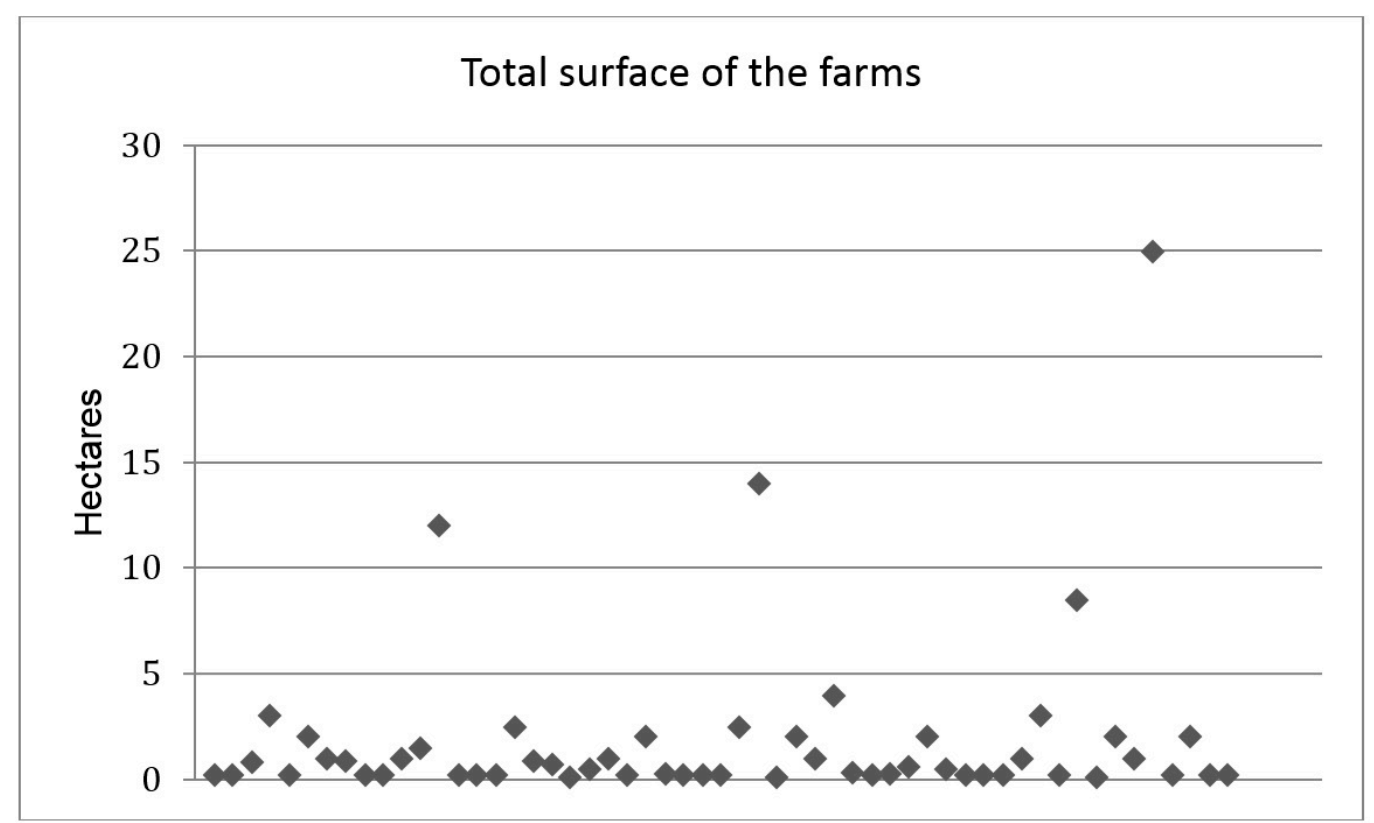

Figure 5. The fragmentation of the agricultural properties is particularly high in the Cinque Terre and Porto Venere area. Almost all the farms have a total area below 5 hectares.

Characteristics of the agricultural productions: Despite the great importance of agricultural activities for the maintenance of a unique cultural landscape and the high quality of the local products, the local agricultural sector is very small in terms of workforce involved and quantity of goods produced. Farmers were asked about the chosen method of cultivation, to see if they are taking advantage of the opportunities given by an evolving market which is increasingly oriented towards high-quality and sustainable produce, with consumers willing to spend more in exchange for better quality. Many farms are 
conducted with conventional methods ( $40 \%$ ), but despite the difficulties of a conversion to more natural methods due to vines' pathogens, almost $47 \%$ of farmers opted for the Integrated Pest Management (IPM) and $12 \%$ for organic farming (Figure 6a). The quality of the products is ensured by the DOP (Protected Designation of Origin) and DOC (Controlled Designation of Origin) certifications that help with market positioning. The main products are related to wine (mainly Cinque Terre DOC and Sciacchetrà DOC) and DOP olive oil, but there are also other popular products (citrus fruits, honey, vegetables). Most farms $(72 \%)$ have concentrated their production only on one product. This choice creates a greater vulnerability because it is subject to market fluctuations, to adverse climatic conditions or to pathogens, but is explained by the small average size of farms and by the fact that farming is the main activity of only $13 \%$ of respondents. Of the sample, $15 \%$ have differentiated production with at least two products, and only a small percentage of farmers achieve a very high degree of differentiation in production (Figure 6b).

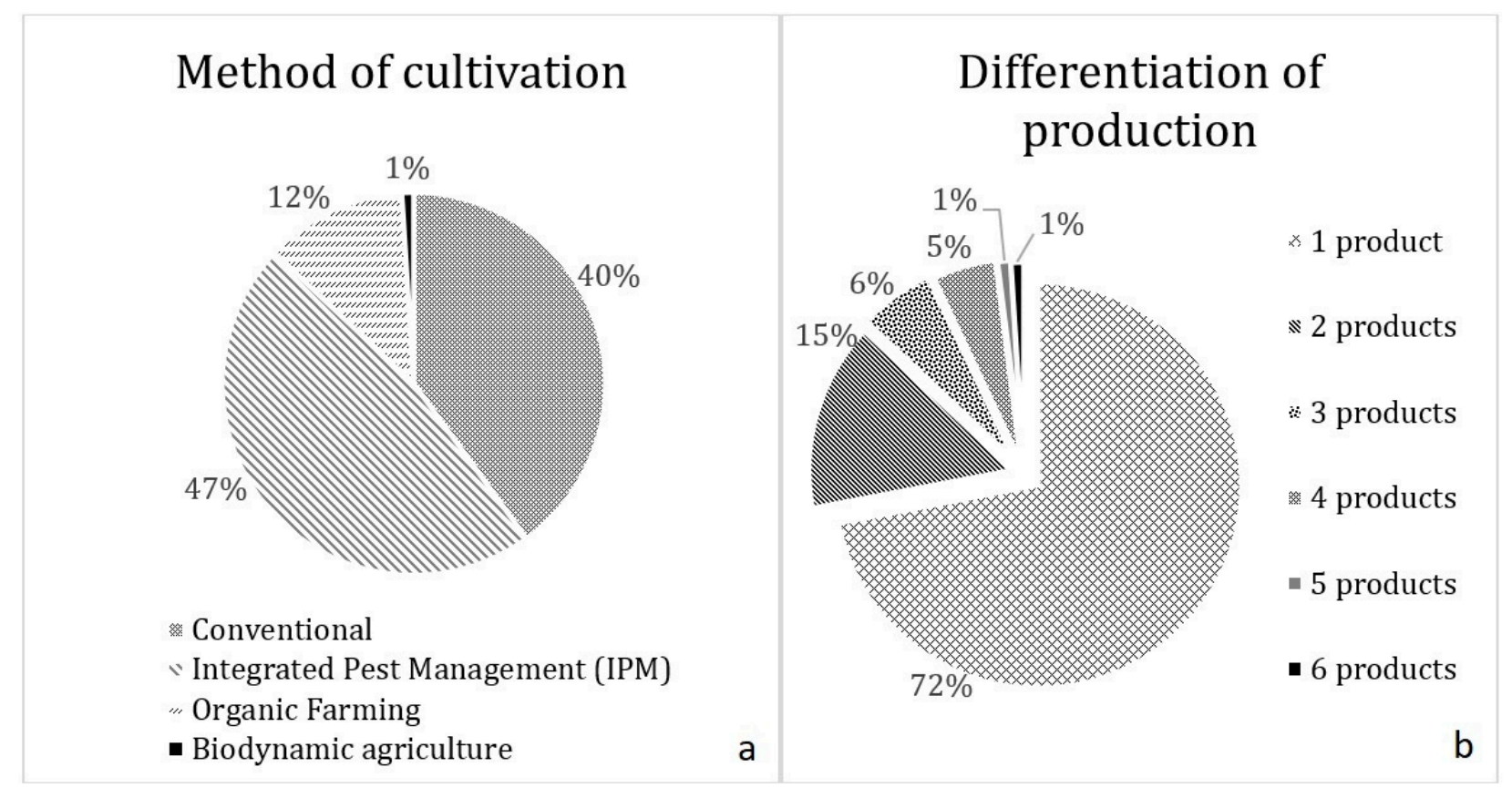

Figure 6. (a) Most farmers have opted for Integrated Pest Management (IPM) or for organic agriculture, (b) but only $28 \%$ have chosen to differentiate the production (right). The low level of differentiation can represent a weakness.

Vines' cultivation: In recent years, the cultivation of the vine is facing a significant transformation. The traditional pergola bassa technique, with the branches left to grow on a pergola made of wooden poles and steel wire, is gradually replaced by rows. Reasons for this are found in a greater ease in performing the different operations (pruning, treatments, planting, harvesting), rather than in an increase of production. The consequence is a certain negative impact on the local landscape, as modern rows are aesthetically very different from the pergola bassa and they are found in almost all the modern vineyards in Europe. Moreover, the pergola bassa completely covers the terrain, and it is therefore more effective in reducing soil erosion during heavy rains. Of the farmers, $63 \%$ continue to cultivate the vines mostly in the traditional way, while $35 \%$ have already changed the training to the row system and $2 \%$ are currently converting them.

Use of Rural Development funds: The funds of the Rural Development Plans 2007-2013 proved to be really effective as a tool for restoring and maintaining the historic landscape. Of the farmers, $94 \%$ applied to receive these funds, to be used for the restoration of dry-stone walls (90\% of the applications).

Multifunctionality of farms and the role of tourism: In such a complex territory, tourism plays a central role, as already mentioned, with positive and negative consequences. 
On the one hand, it increases the market for the local products, representing a chance of economic diversification for the farmers and increasing job opportunities; on the other hand, it has caused a deterioration in the quality of life of the local population, due to the excessive number of tourists and to the prevailing of mass tourism. Questionnaires show how important tourism is for farmers, and consequently for the maintenance of agricultural activities and the Cinque Terre cultural landscape. On a scale from "not important at all" to "crucially important", $84 \%$ of the sample consider tourism to be "very important" or "of crucial importance" for their own farm (Figure 7a), but it seems that this resource is not adequately exploited by the farmers themselves. In fact, $76 \%$ of farms do not offer direct services to tourists, a sign that farmers mainly rely on the tourists who buy their products from other retailers, while only $14 \%$ practice direct sale and $6 \%$ provide accommodation for tourists (Figure 7b).
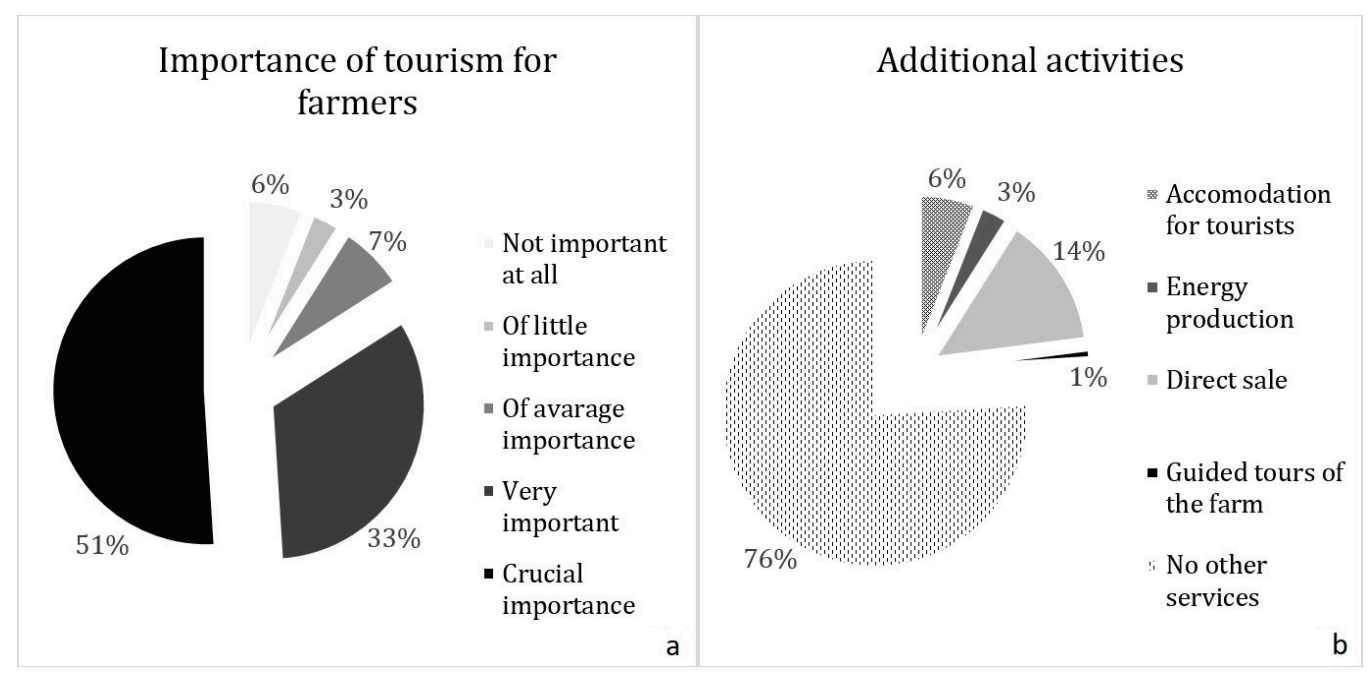

Figure 7. Farmers are not able to adequately intercept tourists and the opportunities related to the great number of visitors that visit the area every year. (a) Tourism represents a fundamental resource for the farmers, (b) but only a few of them offer adequate services to visitors.

\section{Discussion}

Public participation and perception are nowadays considered a priority for landscape planning decision-making, for exploring co-management options, adaptation alternatives and for integrating the knowledge processes which can guide future landscape and nature management policies [71]. Our results showed that the perception of residents and farmers is not always the same. Results also showed that there are no significant differences inside the two groups, and that socio-cultural characteristics (age, gender, level of education, etc.) of the respondents do not seem to statistically influence their opinions. This is something commonly found with other rural areas, as other studies highlighted how people actively involved in agricultural activities hold a higher body of non-scientific knowledge, called local ecological knowledge (LEK), with respect to people visiting the area or living inside the area but not directly involved in agricultural activities [72,73]. The feeling of belonging to a rural and agricultural culture is still perceived by the Cinque Terre population, but this feeling is not equally strong among all the residents, since many have lost their rural roots as they have always been working in the tourism industry. This is also confirmed by the old average age of farmers, although in recent years, a generational turnover has begun. The lower average level of education of farmers does not necessarily correspond to a low level of knowledge and awareness of the landscape, since the experience gained in the field can be much more effective. 
The main difference between farmers and residents refers to the different perception of the woodlands: something thoroughly negative for almost all of the farmers, while residents perceive them partly as an important feature of the landscape and partly as a problem. However, it is possible to identify some common and crucial key points. All the respondents identify the local landscape with the idea of "man-made environment", in which the fundamental features are represented by dry-stone terraces and cultivation of vines and olive trees; in the collective imagination of the respondents, there is a terraced and cultivated landscape, where the wood is the natural frame.

Tourism appears to be the priority area of interventions for both groups and deserves special attention for its consequences on the territory. Worldwide, the relationship between the territories included in the WHL and tourism seems controversial and not always easy to understand, since many authors report a long-standing conflict between heritage protection and tourism development [74-76]. On one side, world heritage sites can attract large numbers of tourists and then generate revenue and create jobs, while on the other side, they can attract excessive numbers of visitors, with the result that the latter have the potential to destroy the environmental and cultural integrity of the World Heritage Sites themselves. Generally seen as a positive factor induced by the creation of the Parks, in the last decade, tourism has caused a worsening of the quality of life for the local population. Despite all the problems related to tourism and the difficulty to make the most of the potential that it could offer for farmers ( $76 \%$ do not provide direct services to tourists), $60 \%$ of the farmers believe that the services offered to tourists should be increased. More than a real desire to increase tourism, the data points to a need to rethink the organization of hospitality and the services provided for this specific territory and to differentiate the types of tourism. Tourism is in fact currently concentrated in the villages, and it is a mainly daytrip tourism, so only a very small part of the revenue gets to farmers, who are the ones who maintain the territory and the landscape of the Site. As happens in other parts of the world, farmers in many rural communities have historically been able to conserve biodiversity and the territory while supporting their livelihoods [77] through the application of traditional practices, as the transmission of knowledge across generations is crucial [72].

The opinion of the farmers has been therefore very useful in addressing the Management Plan. Tourism-related strategies for the area have been addressed to increase the presence of tourists in the rural areas. This could lead to benefits for both the residents, since the overcrowding in the small villages would be reduced, and the farmers, who may increase their incomes that could be reinvested in agricultural activities. The risk, which, in part, has already become the reality, would be that the hospitality activities carried out by farmers would replace the agricultural activity if the incomes from hospitality are significantly higher.

The agricultural sector has significant weaknesses (property fragmentation, lack of cooperation between farmers, lack of services offered directly to tourists, limited direct selling of products), but it also shows some encouraging signs of a slow recovery. In fact, in recent years, there has been a slow but perceptible return by some young people to agricultural activities, together with the spread of local associations of citizens who are involved in restoring dry-stone walls, removing shrubs from abandoned terraces and turning them back into cultivated areas or promoting organic agriculture or IPM.

The strategies developed for the Management Plan intend to encourage local institutions in providing tools and expertise for supporting farmers in offering new services (guided tours to the wineries, tastings, etc.), helping them to reach out more and more to tourists interested in discovering the local products and the local rural life.

The strongest perceived threat, for both groups, is the abandonment of the terraces and the resulting risk of landslides. Despite the fact that the "spread of woodland" was not the first answer chosen, it is possible to state that, especially in the consciousness of the farmers, there is a cause-effect correlation between the abandonment of the terraces, the spread of woodland and the hydrogeological risk. The fact that hospitality activities offer lower risks and higher profits than farming is another threat to agricultural activities. 
The priority sectors of investments identified through the questionnaires reflect the critical issues and the expectations perceived by residents and producers. Farmers call for a greater support from the National Park regarding the applications and the access to Rural Development Plan funds, the availability of skilled workforce for reconstruction the dry-stone walls, the streamlining of bureaucracy and less administrative procedures and permits for removing shrubs and trees on abandoned terraces, where there is a will to recover them for cultivation. Both residents and farmers would advocate that investments in tourism would not lead to an increase in the flows, but to a better distribution in the territory, promoting sustainable tourism and directing it towards the rural part of the territory, relieving the pressure on villages. Finally, investments in the field of land management and for the decrease of hydrogeological risk appear to be crucial.

\section{Conclusions}

Both residents and farmers seem well aware of the vulnerability of their territory and of the strong connections between land abandonment, spread of woodlands and increased hydrogeological risk. To deal with these problems, they call for a stronger support from public authorities, especially with regard to interventions related to hydrogeological risk. Despite that Rural Development Funds proved to be effective and most of the farmers applied for them, they are not sufficient, i.e., even if a farmer restores his/her dry-stone walls and preserves them in perfect condition, if the terraces of neighboring properties, located upstream, are not well preserved, the hydrogeological problems remain, and his/her cultivations are still at risk. Farmers complain that they are the only ones currently taking care of the land, since it is precisely through farm management and drystone walls' restoration that they generate positive externalities and ecosystem services. Territorial management cannot just rely on their willingness to preserve dry-stone walls and continue to cultivate the terraces. If adequately supported, also through the UNESCO site Management Plan, farmers can represent, for local authorities, the most inexpensive and simple system of monitoring and managing this territory. There are many positive local examples supporting this concept and the desire to become more involved in the decision-making processes is evident.

Especially complex territories, characterized by cultural landscapes of high importance, but equally high fragility, have to deal with different critical issues due to significant changes in the social and economic structure, with new challenges to be undertaken. It is also clear that the idea of a "return to nature" as a positive strategy for any rural areas, quite widespread among the citizens, is conflicting with the importance assigned to the agricultural features of this area and with the goals of the UNESCO site and of the National Park. More recently, the Italian Forest Law introduced the possibility of removing secondary vegetation to restore abandoned cultivated land, testifying a change in the vision of public policies at the national level.

The extreme variability of the different UNESCO WHL sites, both at national and international levels, in terms of type, size and type of entities involved in their management, require to find the most suitable form of "governance" each time. The involvement of the population, through the study on landscape perception, critical issues, needs and expectations, carried out through questionnaires to residents and farmers, has proven to be a very effective tool to identify the focus of the Management Plan and some priority lines of action.

Moreover, actively involving the population, not only through the questionnaires but also through public meetings, increases the feeling among the community that the institutions are actually taking care of their problems. In fact, one of the most frequent criticisms was that in recent years, the Parks have disregarded the needs of the citizens, in favor of uncontrollably increasing tourist flows, with particularly negative consequences for the territory. The main limitation regarding the proposed methodology is due to the fact that it takes a lot of time to effectively involve the population, in particular to overcome the initial mistrust, and the support of local authorities is fundamental in organizing public 
meetings. Moreover, as often happens for landscape perception-based studies, another limitation is the lack of solid statistical validation [78].

The exchange of ideas, solutions and views between the population and the decisionmakers, was demonstrated to represent an effective tool in establishing priority guidelines for investments and to reconcile institutions and the community [79], to make Management Plans a more effective instrument in order to preserve and improve the landscape quality and therefore, the quality of people's lives. In fact, results of the questionnaires have been transferred into real strategies and actions for the Management Plan of the UNESCO site and we believe that sharing this kind of experience and methodology could be useful for other planners and scholars who are trying to turn different public participation approaches into real planning instruments. The applied methodology can be easily reproduced in similar situations, to target the management strategies more effectively, especially in the case of cultural landscapes characterized by high quality, complexity and fragility, that due to significant social and economic changes, have to deal with new challenges and transformations.

Author Contributions: Conceptualization and Methodology, A.S., M.V. and M.A.; Writing, M.V. and A.S.; Supervision, A.S. and M.A. All authors have read and agreed to the published version of the manuscript.

Funding: This research received no external funding.

Institutional Review Board Statement: Not applicable.

Informed Consent Statement: Not applicable.

Data Availability Statement: The data presented in this study are available on request from the corresponding author.

Acknowledgments: The authors want to thank Gianfranco Vita from the Cooperativa 5 Terre and all the farmers and the inhabitants of Cinque Terre and Porto Venere.

Conflicts of Interest: The authors declare no conflict of interest.

Appendix A. Questionnaire A-Residents

Interview Profile

1. Age

$16-30$ years

$31-45$ years

$45-60$ years

over 60 years

2. Gender

Male

Female

3. Education level

Primary school

Junior high school

High school

University Degree

4. Why do you frequent the Porto Venere, Cinque Terre and Islands UNESCO Site area?

I live here

I work here

Both 
5. Municipality of residence

La Spezia

Levanto

Monterosso

Porto Venere

Riomaggiore

Vernazza

Other (specify)

6. Occupation

Fisherman/Shellfish farmer

Accommodation or restaurant manager

Accommodation or restaurant employee

Housewife

Shopkeeper

Unemployed

Self-employed

Freelance

Retired

Student

Office worker

Industry worker

Other:

7. Your home or your workplace is located inside:

Cinque Terre National Park

Porto Venere Natural Regional Park

None of them

I do not know

\section{Landscape Perception}

8. In your opinion, what has been the major change in the Porto Venere, Cinque Terre and Islands UNESCO Site's landscape?

Select which are the major changes observed. Mark only one answer.

Land/cultivations abandonment

There are more buildings

Cultivation type changes

Forestation process

Higher landscape attention

Landslides increase

9. Do you think wood is a fundamental feature of the local landscape?

Yes, a lot

No, a little

I do not know

10. Give a score from 1 to 5 to each UNESCO Site landscape element according to its importance for the valorization of the area

$1=$ minimum score and $5=$ maximum score. Mark only one value per row.

12345

Terraced olive groves

Terraced vineyards

Mediterranean maquis 
Vegetable gardens

Arable land

Pastures

Chestnut woods

Conifer forest (pinus)

Broadleaf forest (quercus)

11. Observing the following pictures, which landscape do you prefer? (see Figure 4)

A

B

C

12. Do you think that agriculture activities are compatible with Cinque Terre National Park aims? (for the inhabitants or the ones who work inside the National Park)

Yes

No

I do not know

13. Do you think that agriculture activities are compatible with Porto Venere Natural Regional Park aims? (for the inhabitants or the ones who work inside the Regional Park)

Yes

No

I do not know

14. Have you perceived landscape changes since the area has been recognized as Cinque Terre National Park (1999) and Porto Venere Regional Natural Park (2001)? (if yes, please describe which is the main change observed)

Yes:

No

I do not know

15. Which of the following aspects do you think that the Cinque Terre National Park needs to protect more?

Landscape

Agriculture and livestock

Nature

Hydrogeological risk protection

Tourism

Road network and public transports

Other:

16. Which of the following aspects do you think that the Porto Venere Regional Natural Park needs to protect more?

Landscape

Agriculture and livestock

Nature

Hydrogeological risk protection

Tourism

Road network and public transports

Other:

Appendix B. Questionnaire B-Farmers

Company Owner Profile 
1. Age

16-30 years

$31-45$ years

45-60 years

over 60 years

2. Gender

Male

Female

3. Education level

Primary school

Junior high school

High school

University Degree

4. Municipality of residence

La Spezia

Monterosso

Levanto

Porto Venere

Riomaggiore

Vernazza

Other:

5. Is Agriculture your main activity?

Yes

No

6. Are you a certified agricultural entrepreneur?

Yes

No

7. Your farm is inside of:

Parco Nazionale delle Cinque Terre

Parco Regionale Naturale di Porto Venere

None of them

\section{Landscape Perception}

8. In your opinion, what has been the major change in the Porto Venere, Cinque Terre and Islands UNESCO Site landscape? Select which are the major changes observed. Mark only one answer.

Land/cultivations abandonment

There are more buildings

Cultivations types changes

Forestation process

Higher landscape attention

Landslides increase

9. Do you think wood is a fundamental feature of the local landscape?

Yes, a lot

No, a little

I do not know 
10. Give a score from 1 to 5 to each UNESCO Site landscape element according to its importance for the valorization of the area

$1=$ minimum score and $5=$ maximum score. Mark only one value per row.

\section{5}

Terraced olive groves

Terraced vineyards

Mediterranean maquis

Vegetable gardens

Arable land

Pastures

Chestnuts woods

Conifer forest (pinus)

Broadleaf forest (quercus)

11. Observing the following pictures, which landscape do you prefer? (see Figure 4)

A

B

C

12. Have you perceived landscape changes since the area has been recognized as Cinque Terre National Park (1999) and Porto Venere Regional Natural Park (2001)? (if yes, please describe which is the main change observed)

Yes:

No

I do not know

13. Which of the following aspects do you think that the Cinque Terre National Park needs to protect more? (for the farms inside the National Park borders)

Landscape

Agriculture and livestock

Nature

Hydrogeological risk protection

Tourism

Road network and public transports

Other:

14. Which of the following aspects do you think that the Porto Venere Regional Natural Park needs to protect more? (for the farms inside the Regional Park and Porto Venere)

Landscape

Agriculture and livestock

Nature

Hydrogeological risk protection

Tourism

Road network and public transports

Other:

\section{Farm Multifunctionality and Tourism}

15. In your farm, do you carry out one or more of the following activities?

Select all the applicable answers.

Energy production (solar, biomass, etc.)

Accommodation (agritourism, Bed \& Breakfast, etc.)

Social activities (educational farm, social vegetable gardens, etc.)

Direct sale of food products

Other: 
16. How much tourism is important for your activity?

(Select from 1 to 5 according to the relevance of tourism for your farm in terms of sales, disclosure of your products, hosting activities, etc). $1=$ minimum, $5=$ maximum score .

\section{5}

Low relevance very relevant

17. If your farm carries out touristic activities, where are tourists mostly from?

Italy

Other European countries

North America

Asia

South America

18. Do you think is it necessary to improve the touristic offer in the UNESCO site in order to develop the local economy?

Yes

No

19. What kind of activities/services are more requested by tourists?

If "Other", specify what kind of activity (guided tours, educational farms, etc.)

Accommodation

Restaurant

Cellar visit, tasting

Direct sale of agricultural products

Other:

\section{Information about the Farm}

20. Which kind of products do you produce on your farm? Select all the applicable answers.

Sciacchetrà Wine

DOC Cinque Terre Wine

DOC Colline di Levanto Wine

IGT Liguria di Levante (or IGT Golfo dei Poeti) Wine

Honey

Oil DOP Riviera Ligure

Citrus fruits

Olives

Other:

21. If there are vineyards on your farm, they are mostly cultivated with:

Row technique (guyot, sylvoz)

Pergola bassa traditional technique

Under conversion from pergola to row

22. Please specify the total farm surface in hectares

23. On your farm, are there uncultivated lands? If yes, specify the abandonment motivations and the uncultivated lands' surface in hectares.

Yes,

No

24. Are the fields of your farm owned or rented?

Owned

Rented

25. Is your farm a family farm?

Yes

No 
26. Do you collaborate with other farms? If yes, specify which kind of collaborations you have with the other farms

Yes,

No

27. Do you directly take care of the transformation processes of your agricultural products?

Yes

No

28. What kind of agriculture do you practice on your farm?

Conventional

Integrated

Organic

Biodynamic

29. Are your productions certified? (i.e., PDO, DOC, DOCG, IGT, Organic)

Yes

No

30. Which is the target market for your products? Select all the applicable answers.

Cinque Terre and/or Porto Venere shops

Direct sale in the farm

Web

Social sale groups (GAS)

Social canteen

Other:

31. Have you requested financial support through the Rural Development Program funds?

No

Yes, for restoring dry-stone walls

Yes, for monorails

Yes, for other purposes:

32. In which phase are the projects financed through the Rural Development Program funds?

Still not started

In realization phase

Searching for sponsors/public resources

Concluded

Problems and Future Perspectives

33. In which of the following aspects do you think that the Cinque Terre National Park needs to take more care? (for the farms inside the National Park borders)

Coordination and collaboration among producers

Nature conservation

Hydrogeological and landslides risk protection

Tourism and economic activities

Road network and public transport implementation

Other:

34. In which of the following aspects do you think that the Porto Venere Regional Park needs to take more care? (for the farms inside the Regional Park borders)

Coordination and collaboration among producers

Nature conservation

Hydrogeological and landslides risk protection

Tourism and economic activities 
Road network and public transport implementation

Other:

35. Which public body do you think needs to be more interested in problems and management activities in the UNESCO Site area?

Cinque Terre National Park

Porto Venere Natural Regional Park

Liguria Region

La Spezia Province

Basin Authority

Municipalities

36. Which are the main problematic issues for your farm? Select all the applicable answers.

Poor road and path network

Excessive public bodies bureaucracy

Damages caused by wild fauna (wild pigs, ungulates, etc.)

Lack of workforce

Low awareness of the area value expressed by tourists

37. In the future, do you think you will be interested in carrying out educational, museal, eno-gastronomic, recreational and touristic activities to implement the touristic offer in the UNESCO Site?

Yes

No

\section{References}

1. Agnoletti, M.; Santoro, A. Cultural values and sustainable forest management: The case of Europe. J. For. Res. 2015, 20, 438-444. [CrossRef]

2. Geri, F.; Amici, V.; Rocchini, D. Human activity impact on the heterogeneity of a Mediterranean landscape. Appl. Geogr. 2010, 30, 370-379. [CrossRef]

3. Antrop, M. Why landscapes of the past are important for the future. Landsc. Urban Plan. 2005, 70, 21-34. [CrossRef]

4. Jongman, R.H.G. Homogenisation and fragmentation of the European landscape: Ecological consequences and solutions. Landsc. Urban Plan. 2002, 58, 211-221. [CrossRef]

5. Kizos, T.; Koulouri, M. Agricultural landscape dynamics in the Mediterranean: Lesvos (Greece) case study using evidence from the last three centuries. Environ. Sci. Policy 2006, 9, 330-342. [CrossRef]

6. Marignani, M.; Rocchini, D.; Torri, D.; Chiarucci, A.; Maccherini, S. Planning restoration in a cultural landscape in Italy using an object-based approach and historical analysis. Landsc. Urban Plan. 2008, 84, 28-37. [CrossRef]

7. Palang, H.; Mander, U.; Aarne, L. Landscape diversity changes in Estonia. Landsc. Urban Plan. 1998, 41, 163-169. [CrossRef]

8. Lipský, Z. Methods of Monitoring and Assessment of Changes in Land Use and Landscape Structure. Ekol. Kraj. 2007, 0, $105-118$.

9. Vos, W.; Meekes, H. Trends in European cultural landscape development: Perspectives for a sustainable future. Landsc. Urban Plan. 1999, 46, 3-14. [CrossRef]

10. Wei, W.; Chen, D.; Wang, L.; Daryanto, S.; Chen, L.; Yu, Y.; Lu, Y.; Sun, G.; Feng, T. Global synthesis of the classifications, distributions, benefits and issues of terracing. Earth-Sci. Rev. 2016, 159, 388-403. [CrossRef]

11. Stanchi, S.; Freppaz, M.; Agnelli, A.; Reinsch, T.; Zanini, E. Properties, best management practices and conservation of terraced soils in Southern Europe (from Mediterranean areas to the Alps): A review. Quat. Int. 2012, 265, 90-100. [CrossRef]

12. Farina, A. (Ed.) Principles and Methods in Landscape Ecology; Chapman \& Hall: London, UK, 1998.

13. Lundström-Gilliéron, C.; Schlaepfer, R. Hare abundance as an indicator for urbanisation and intensification of agriculture in Western Europe. Ecol. Model. 2003, 168, 283-301. [CrossRef]

14. De Aranzabal, I.; Schmitz, M.F.; Aguilera, P.; Pineda, F.D. Modelling of landscape changes derived from the dynamics of socio-ecological systems: A case of study in a semiarid Mediterranean landscape. Ecol. Indic. 2008, 8, 672-685. [CrossRef]

15. Schmitz, M.F.; de Aranzabal, I.; Aguilera, P.; Rescia, A.; Pineda, F.D. Relationship between landscape typology and socioeconomic structure. Scenarios of change in Spanish cultural landscapes. Ecol. Model. 2003, 168, 343-356. [CrossRef]

16. UNESCO. Convention Concerning the Protection of the World Cultural and Natural Heritage, Proceedings of the Twenty-First Session, Naples, Italy, 1-6 December 1997; World Heritage Committee: Paris, France, 1997.

17. D'Amato Avanzi, G.; Galanti, Y.; Giannecchini, R.; Mazzali, A.; Saulle, G. Remarks on the 25 October 2011 rainstorm in Eastern Liguria and Northwestern Tuscany (Italy) and the related landslides. Rend. Online Soc. Geol. Ital. 2013, 24, 76-78. 
18. Council of Europe. The European Landscape Convention; Council of Europe: Strasbourg, France, 2000; Available online: http: / / conventions.coe.int/Treaty/en/Treaties/Html/176.htm (accessed on 20 January 2021).

19. Ministero per i Beni e le Attività Culturali. Progetto di Definizione di un Modello per la Realizzazione dei Piani di Gestione dei siti UNESCO; Ministero per i Beni e le Attività Culturali: Rome, Italy, 2005.

20. Eiter, S.; Vik, M.L. Public participation in landscape planning: Effective methods for implementing the European Landscape Convention in Norway. Land Use Policy 2015, 44, 44-53. [CrossRef]

21. Stoll-Kleemann, S.; De la Vega-Leinert, A.C.; Schultz, L. The role of community participation in the effectiveness of UNESCO Biosphere Reserve management: Evidence and reflections from two parallel global surveys. Environ. Conserv. 2010, 37, 227-238. [CrossRef]

22. Coeterier, J.F. Lay people evaluation of historic sites. Landsc. Urban Plan. 2002, 59, 111-123. [CrossRef]

23. Prieur, M.; Durousseau, S. Landscape and public participation. In Landscape and Sustainable Development-Challenges of the European Landscape Convention; Council of Europe Publishing: Strasbourg, France, 2006.

24. Dian, A.M.; Abdullah, N.C. Public participation in heritage sites conservation in Malaysia: Issues and challenges. Procedia Soc. Behav. Sci. 2013, 101, 248-255. [CrossRef]

25. Bruns, D. Cultural Landscape: All That People Give Value to in Their Surroundings. In Basic and Clinical Environmental Approaches in Landscape Planning; Shimizu, H., Murayama, A., Eds.; Springer: Berlin/Heidelberg, Germany, 2014; pp. 3-13.

26. Paavola, J.; Hubacek, K. Ecosystem services, governance, and stakeholder participation: An introduction. Ecol. Soc. 2013, 18, 42. [CrossRef]

27. Santoro, A.; Venturi, M.; Agnoletti, M. Agricultural Heritage Systems and Landscape Perception among Tourists. The Case of Lamole, Chianti (Italy). Sustainability 2020, 12, 3509. [CrossRef]

28. United Nations. Convention on Biological Diversity. 1992. Available online: https://www.cbd.int/doc/legal/cbd-en.pdf (accessed on 20 January 2021).

29. United Nations Economic Commission for Europe. Aarhus Convention. 1998. Available online: https://treaties.un.org/doc/ Treaties/1998/06/19980625\%2008-35\%20AM/Ch_XXVII_13p.pdf (accessed on 20 January 2021).

30. Selman, P. Community participation in the planning and management of cultural landscapes. J. Environ. Plan. Manag. 2004, 47, 365-392. [CrossRef]

31. Stenseke, M. Local participation in cultural landscape maintenance: Lessons from Sweden. Land Use Policy 2009, 26, 214-223. [CrossRef]

32. Ryan, C.; Chaozhi, Z.; Zeng, D. The impacts of tourism at a UNESCO heritage site in China-A need for a meta-narrative? The case of the Kaiping Diaolou. J. Sustain. Tour. 2011, 19, 747-765. [CrossRef]

33. Compagnoni, C. Biblioteca Storica di Diodoro Siculo Tomo Secondo; Tipografia di Gian Battista Sonzogno: Milan, Italy, 1820.

34. Marmocchi, F.C. Descrizione dell'Italia; Poligrafica Italiana: Florence, Italy, 1846.

35. Terranova, R. Il paesaggio costiero terrazzato delle Cinque Terre in Liguria. Studi Ric. Geogr. 1989, XII, 1-58.

36. UNESCO. Advisory Board Evaluation; UNESCO: Paris, France, 1998.

37. Gasparini, G.P. (Ed.) Il Vino delle Cinque Terre e le Trasformazioni Ottocentesche; Philobiblon Edizioni: Ventimiglia, Italy, 2001.

38. ISTAT. Censimento Generale dell'Agricoltura 2010; ISTAT: Rome, Italy, 2010.

39. Istituto Centrale di Statistica del Regno d'Italia. Catasto Agrario 1929; Istituto Poligrafico dello Stato: Rome, Italy, 1934.

40. UNESCO, sCBD. Florence Declaration on the Links between Biological and Cultural Diversity. Florence, Italy, 2014. Available online: https: / / www.google.com/url?sa=t\&rct=j\&q=\&esrc=s\&source=web\&cd=1\&cad=rja\&uact=8\&ved=2ahUKEwiUhKTxgP7

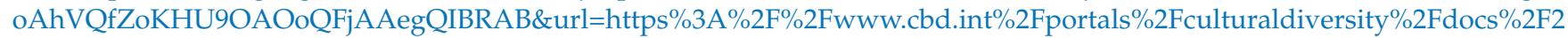
1040410-declaration-florence-en.pdf\&usg=AOvVaw1Vc6WNrfl_ur7g7dSeXGl3 (accessed on 5 January 2021).

41. Agnoletti, M. Rural landscape, nature conservation and culture: Some notes on research trends and management approaches from a (southern) European perspective. Landsc. Urban Plan. 2014, 126, 66-73. [CrossRef]

42. Fukamachi, K.; Oku, H.; Nakashizuka, T. The change of a satoyama landscape and its causality in Kamiseya, Kyoto Prefecture, Japan between 1970 and 1995. Landsc. Ecol. 2001, 16, 703-717. [CrossRef]

43. García-Ruiz, J.M.; Lasanta, T.; Ruiz Flaño, P.; Ortigosa, L.M.; White, S.; González, C.; Martí, C. Land-use changes and sustainable development in mountain areas: A case study in the Spanish Pyrenees. Landsc. Ecol. 1996, 11, 267-277. [CrossRef]

44. Harden, C. Interrelationships between abandonment and land degradation: A case from the Ecuadorian Andes. Mt. Res. Dev. 1996, 16, 274-280. [CrossRef]

45. Lasanta, T.; García-Ruiz, J.M.; Pérez Rontomé, M.C.; Sancho, C. Runoff and sediment yield in a semi-arid environment: The effect of land management after farmland abandonment. Catena 2000, 38, 265-278. [CrossRef]

46. Khanal, N.; Watanabe, T. Abandonment of agricultural land and its consequences. Mt. Res. Dev. 2006, 26, 32-40. [CrossRef]

47. Sanchez-Maranon, M.; Soriano, M.; Delgado, G.; Delgado, R. Soil quality in Mediterranean mountain environments. Effects of land use change. Soil Sci. Soc. Am. J. 2002, 66, 948-958.

48. Londoño, A.C. Pattern and rate of erosion inferred from Inca agricultural terraces in arid southern Peru. Geomorphology 2008, 99, 13-25. [CrossRef]

49. Sang-Arun, J.; Mihara, M.; Horaguchi Yamaji, Y. Soil erosion and participatory remediation strategy for bench terraces in Northern Thailand. Catena 2006, 65, 258-264. [CrossRef] 
50. Agnoletti, M.; Errico, A.; Santoro, A.; Dani, A.; Preti, F. Terraced landscapes and hydrogeological risk. The effects of land abandonment in Cinque Terre (Italy) during severe rainfall events. Sustainability 2019, 11, 235. [CrossRef]

51. Brandolini, P.; Cevasco, A.; Capolongo, D.; Pepe, G.; Lovergine, F.; Del Monte, M. Response of terraced slopes to a very intense rainfall event and relationships with land abandonment: A case study from Cinque Terre (Italy). Land Degrad. Dev. 2018, 29, 630-642. [CrossRef]

52. Ruiz-Flaño, J.; García-Ruiz, J.; Ortigosa, L. Geomorphologial evolution of abandoned fields. A case study in the Central Pyrenees. Catena 1992, 19, 301-308. [CrossRef]

53. Brancucci, G.; Masetti, M. Terraced systems: Heritage and risk. In Terraced Landscapes of the Alps: Atlas; Scaramellini, G., Varotto, M., Eds.; Marsilio: Venice, Italy, 2008; pp. 46-53.

54. Daugstad, K. Negotiating landscape in rural tourism. Ann. Tour. Res. 2008, 35, 402-426. [CrossRef]

55. Butler, R.; Hall, C.; Jenkins, J. (Eds.) Tourism and Recreation in Rural Areas; Wiley: Chichester, UK, 1998.

56. Kneafsey, M. Tourism, place identities and social relations in the European rural periphery. Eur. Urban Reg. Stud. 2000, 7, 35-50. [CrossRef]

57. ISTAT. Censimento dell'Industria e dei Servizi 2011; ISTAT: Rome, Italy, 2011.

58. Zube, E.H.; Simcox, D.E.; Law, C.S. Perceptual Landscape Simulations: History and Prospect. Landsc. J. 1987, 6, 62-80. [CrossRef]

59. Zube, E.; Sell, J.; Taylor, J. Landscape perception: Research, application and theory. Landsc. Plan. 1982, 9, 1-33. [CrossRef]

60. Purcell, A.; Lamb, R.; Mainardi Peron, E.; Falchero, S. Preference or preferences for landscape? J. Environ. Psychol. 1994, 14, 195-209. [CrossRef]

61. Ribe, R.G. The aesthetics of forestry: What has empirical preference research taught us? Environ. Manag. 1989, 13, 55-74. [CrossRef]

62. Kaplan, R. The perception of landscape style: A cross-cultural comparison. Landsc. Urban Plan. 1990, 19, $251-262$.

63. Thompson, C.W. Landscape perception and environmental psychology. In The Routledge Companion to Landscape Studies; Routledge: Abingdon, UK, 2013; pp. 43-60.

64. Boselli, V.; Ouallali, A.; Briak, H.; Houssni, M.; Kassout, J.; El Ouahrani, A.; Michailidi, E.M. System Dynamics Applied to Terraced Agroecosystems: The Case Study of Assaragh (Anti-Atlas Mountains, Morocco). Water 2020, 12, 1693. [CrossRef]

65. Bird, D.K. The use of questionnaires for acquiring information on public perception of natural hazards and risk mitigation-a review of current knowledge and practice. Nat. Hazards Earth Syst. Sci. 2009, 9, 1307. [CrossRef]

66. De Marinis, P.; Mazzocchi, C.; Sali, G. Perception of Microgardens in Dakar, Senegal. J. Agric. Environ. Int. Dev. 2020, 114, 77-98.

67. Tempesta, T. The perception of agrarian historical landscapes: A study of the Veneto plain in Italy. Landsc. Urban Plan. 2010, 97, 258-272. [CrossRef]

68. Torquati, B.; Giacchè, G.; Tempesta, T. Landscapes and Services in Peri-Urban Areas and Choice of Housing Location: An Application of Discrete Choice Experiments. Land 2020, 9, 393. [CrossRef]

69. Dupont, L.; Antrop, M.; Van Eetvelde, V. Eye-tracking analysis in landscape perception research: Influence of photograph properties and landscape characteristics. Landsc. Res. 2014, 39, 417-432. [CrossRef]

70. Myers, M.S.; Thompson, C.W. Interviews and questionnaires. In Integrated, Participatory Landscape Planning as a Tool for Rural Development; Forestry Commission: Edinburgh, UK, 2003; p. 17.

71. Palomo, I. Climate change impacts on ecosystem services in high mountain areas: A literature review. Mt. Res. Dev. 2017, 37, 179-187. [CrossRef]

72. Cebrián-Piqueras, M.; Filyushkina, A.; Johnson, D.N.; Lo, V.B.; López-Rodríguez, M.D.; March, H.; Oteros-Rozas, E.; PepplerLisbach, C.; Quintas-Soriano, C.; Raymond, C.M.; et al. Scientific and local ecological knowledge, shaping perceptions towards protected areas and related ecosystem services. Landsc. Ecol. 2020, 35, 2549-2567. [CrossRef]

73. Ode, Å.; Fry, G.; Tveit, M.S.; Messager, P.; Miller, D. Indicators of perceived naturalness as drivers of landscape preference. J. Environ. Manag. 2009, 90, 375-383. [CrossRef] [PubMed]

74. Drost, A. Developing sustainable tourism for world heritage sites. Ann. Tour. Res. 1996, 23, 479-484. [CrossRef]

75. Yang, C.H.; Lin, H.L.; Han, C.C. Analysis of international tourist arrivals in China: The role of World Heritage Sites. Tour. Manag. 2010, 31, 827-837. [CrossRef]

76. Cellini, R. Is UNESCO recognition effective in fostering tourism? A comment on Yang, Lin and Han. Tour. Manag. 2011, 32, 452-454. [CrossRef]

77. Berkes, F. Sacred ecology: Traditional Ecological Knowledge and Resource Management; Taylor \& Francis: Philadelphia, PA, USA, 1999.

78. Simensen, T.; Halvorsen, R.; Erikstad, L. Methods for landscape characterisation and mapping: A systematic review. Land Use Policy 2018, 75, 557-569. [CrossRef]

79. Ryan, R.L. The social landscape of planning: Integrating social and perceptual research with spatial planning information. Landsc. Urban Plan. 2011, 100, 361-363. [CrossRef] 